DOI:10.17951/h.2019.53.4.115-127

\begin{tabular}{lcc}
\hline \multicolumn{1}{c}{ A N N A L E S } \\
UNIVERSITATIS MARIAE CURIE-SKŁODOWSKA \\
LUBLIN - POLONIA \\
VOL. LIII, 4 & SECTIOH H \\
\hline
\end{tabular}

\author{
ANNA MOŹDZIERZ \\ anna.mozdzierz@uek.krakow.pl \\ Uniwersytet Ekonomiczny w Krakowie. Kolegium Ekonomii, Finansów i Prawa \\ ul. Rakowicka 27, 31-510 Kraków, Polska \\ ORCID ID: https://orcid.org/0000-0003-1292-0798
}

\title{
Wpływ reguly wydatkowej na typ polityki fiskalnej w Polsce
}

The Impact of the Expenditure Rule on the Type of Fiscal Policy in Poland

Keywords: fiscal rule; expenditure rule; fiscal policy

Słowa kluczowe: reguła fiskalna; reguła wydatkowa; polityka fiskalna

JEL: E30; E31; E62

Propozycja cytowania: Moździerz, A. (2019). Wpływ reguły wydatkowej na typ polityki fiskalnej w Polsce. Annales Universitatis Mariae Curie-Sktodowska, sectio H-Oeconomia, Vol. 53, No. 4.

\footnotetext{
Abstract

Theoretical background: Presentation of Polish experiences with the introduction of the expenditure rule into the Polish law under the influence of EU regulations.

Purpose of the article: Demonstration that the modification of the expenditure rule carried out in 2015 resulted in the loss of its stabilising nature, which was supposed to be its main feature.

Research methods: The changes in the fiscal policy stance in 2013-2018 were identified on the basis of annual changes in the ratio of cyclically-adjusted primary balance to output gap.

Main findings: The analyses carried out in the paper showed that the expenditure rule in its original shape was conducive to mitigation of economic fluctuations. After the reduction of the restrictiveness of the expenditure rule in 2015, consisting in replacing the inflation target with medium-term inflation target, it no longer played a stabilising role. The conclusion of the article is that well-constructed numerical fiscal rules may be an important instrument for maintaining control over the state of public finances, but experiences with the expenditure rule in Poland provide many arguments to opponents of the application of numerical rules in fiscal policy.
} 


\begin{abstract}
Abstrakt
Uzasadnienie teoretyczne: Przedstawienie polskich doświadczeń z wprowadzaniem reguły wydatkowej do krajowego prawa pod wpływem regulacji unijnych.

Cel artykułu: Wykazanie, że modyfikacja reguły wydatkowej z 2015 r. skutkowała utratą jej stabilizującego charakteru, który miał stanowić jej główną właściwość.

Metody badawcze: Identyfikacji zmian w nastawieniu w polityce fiskalnej w latach 2013-2018 dokonano na podstawie zmian w ujęciu rocznym salda pierwotnego dostosowanego cyklicznie względem luki produkcyjnej.

Glówne wnioski: Przeprowadzone w pracy analizy wykazały, że reguła wydatkowa funkcjonująca w pierwotnym kształcie sprzyjała łagodzeniu wahań koniunkturalnych. Wraz ze zmniejszeniem restrykcyjności reguły wydatkowej w 2015 r., polegającej na zastąpieniu w formule wskaźnika prognozowanej inflacji wskaźnikiem średniookresowego celu inflacyjnego, jej funkcja stabilizująca została zatracona. Stwierdzono, że dobrze skonstruowane numeryczne reguły fiskalne mogą być ważnym instrumentem zachowania kontroli nad stanem finansów publicznych, lecz doświadczenia z regułą wydatkową w Polsce dostarczają wielu argumentów przeciwnikom stosowania reguł numerycznych w polityce fiskalnej.
\end{abstract}

\title{
Wprowadzenie
}

W ostatniej dekadzie nastąpił istotny wzrost znaczenia numerycznych reguł fiskalnych jako instrumentów dyscyplinowania finansów publicznych. W przebudowanym systemie nadzoru fiskalnego w UE, po doświadczeniach kryzysu finansowego, numerycznym regułom fiskalnym również przypisano większą rangę, zarówno w wymiarze krajowym, jak i ponadnarodowym (Próchnicki 2013; Moździerz, 2015). Wyrazem tego było m.in. zobowiązanie państw członkowskich do stosowania reguły wydatkowej uzależniającej roczne tempo wzrostu wydatków publicznych od średniookresowego tempa wzrostu potencjalnego PKB (Council Directive 2011/85/ EU of 8 November 2011). W wyniku wprowadzenia dyrektywy reguła wydatkowa stała się elementem polskiego porządku prawnego od $2013 \mathrm{r}$.

W teorii skuteczność reguł fiskalnych uzależnia się od ich trzech właściwości: prostoty, elastyczności i wykonalności. Tworzenie reguł „drugiej generacji”, łączących w sobie cele zrównoważonego rozwoju z potrzebą elastyczności w reakcji na wstrząsy, doprowadziło do wzrostu stopnia skomplikowania ich konstrukcji. Jak twierdzą Eyraud, Debrun, Hodge, Lledó i Pattillo (2018, s. 4), wzrostowi jakości reguł nie towarzyszyła stosowna poprawa dyscypliny fiskalnej.

Przedmiotem artykułu jest przedstawienie polskich doświadczeń z wprowadzaniem reguły wydatkowej do krajowego prawa pod wpływem regulacji unijnych. ${ }^{1}$ Celem jest wykazanie, że modyfikacja stabilizacyjnej reguły wydatkowej z 2015 r. skutkowała utratą jej właściwości polegającej na stabilizowaniu wahań koniunkturalnych. Identyfikacji zmian w nastawieniu w polityce fiskalnej w latach 2013-2018 dokonano na podstawie analizy zmian w ujęciu rocznym salda pierwotnego dosto-

1 Doświadczenia Polski z wprowadzaniem także innych reguł numerycznych opisano w: (Moździerz, 2018). 
sowanego cyklicznie (CABP) względem luki produkcyjnej. Okres, jaki upłynął od wprowadzenia reguły, nie pozwala na przeprowadzenie badań statystycznych potwierdzających słuszność przyjętych założeń z uwagi na zbyt krótkie szeregi czasowe danych. Dostrzegając te ograniczenia, wyniki analiz zaprezentowanych w niniejszym opracowaniu należy traktować jako przyczynek do dalszych badań.

\section{Unijna reguła wydatkowa - innowacja czy zagrożenie dla państw członkowskich UE? Przegląd literatury}

Numeryczne reguły fiskalne, uwzględniające specyfikę danego kraju, są istotnym elementem ram budżetowych krajów członkowskich UE (Moździerz 2017, s. 108-110). Elementem ram budżetowych mają być też numeryczne reguły fiskalne, uwzględniające specyfikę danego kraju. Komisja Europejska zakłada, że nałożenie ograniczeń na dyskrecjonalne decyzje fiskalne rządów będzie sprzyjać rozsądnej (odpowiedzialnej) polityce fiskalnej (European Commission, 2010, s. 99). Atrakcyjność reguł fiskalnych jest prezentowana zwłaszcza w kontekście ich przydatności w dyscyplinowaniu finansów publicznych, ograniczania cykliczności procesów gospodarczych czy tzw. odpolitycznienia finansów publicznych (Buchanan, 1997, s. 130). Eksponowane jest znaczenie reguł dla zwiększenia przewidywalności działań w sektorze publicznym, ograniczające możliwość nieodpowiedzialnych zachowań polityków (Postuła i Klepacki, 2018, s. 294).

W odniesieniu do strefy euro wskazuje się dodatkowe oczekiwanie wobec reguł, że pozwolą ograniczyć pokusę nadużycia (moral hazard) (Berger, Dell'Ariccia i Obstfeld, 2018, s. 2) polegającą na większej skłonności do prowadzenia nieodpowiedzialnej polityki fiskalnej, której koszty w postaci wzrostu stóp procentowych poniosą wszystkie kraje posługujące się wspólną walutą. Unifikacja monetarna przy zachowaniu suwerennych polityk fiskalnych osłabia więc dyscyplinę fiskalną w krajach członkowskich (Beetsma i Bovenberg, 2001). Pokusa nadużycia w strefie euro $\mathrm{w}$ okresie poprzedzającym kryzys przejawiała się skłonnością do prowadzenia luźnej polityki fiskalnej. Z punktu widzenia podjętej problematyki warto odnotować jedno z dziesięciu przykazań dla reguły fiskalnej w $\mathrm{E}(\mathrm{M}) \mathrm{U}$, sformułowanych przez Buitera (2003, s. 84-99), zgodnie z którym reguła fiskalna nie powinna zachęcać do wykorzystania instrumentów polityki fiskalnej w sposób powodujący nasilenie wahań koniunkturalnych. Wyznaczenie optymalnej reguły wydatkowej pozostaje przedmiotem badań empirycznych. Przykładem może być koncepcja reguł sprzężenia zwrotnego, których zastosowanie pozwala gospodarce rozwijać się zgodnie z pożądanymi ścieżkami (Przybylska-Mazur, 2017).

Testem dla skuteczności reguł fiskalnych był światowy kryzys finansowy zapoczątkowany w $2008 \mathrm{r}$. Z badań ankietowych przeprowadzonych w kwietniu $2009 \mathrm{r}$. przez Międzynarodowy Fundusz Walutowy na próbie 72 krajów świata wynika, że doświadczenia krajów z regułami w warunkach kryzysu były różne (IMF, 2009, 
s. 34-36). W 31 krajach (43\% przypadków) nie zgłoszono potrzeby zmian istniejących reguł, w 25 krajach (35\%) nie dokonano zmian, lecz reakcja polityczna na kryzys nie była w pełni zgodna z regułami, a w 16 krajach (22\%) dokonano zmiany $\mathrm{w}$ konstrukcji istniejących reguł lub wprowadzono nowe w reakcji na kryzys.

Nowe reguły fiskalne to te, które wprowadzono po kryzysie zarówno na szczeblu krajowym, jak i unijnym. Jedną z nich jest reguła wydatkowa, zgodnie z którą w krajach, które osiągnęły średniookresowy cel budżetowy (MTO), roczne tempo wzrostu wydatków nie może przekraczać referencyjnego średniookresowego tempa wzrostu potencjalnego PKB. Natomiast w przypadku krajów, które jeszcze nie osiągnęły MTO, tempo wzrostu wydatków musi być niższe od tempa wzrostu potencjalnego PKB (Regulation (EU) No. 1175/2011 of the European Parliament and of the Council of 16 November 2011, art. 2a pkt 12). Hipotetyczny charakter potencjalnego PKB skutkuje trudnościami jego pomiaru. Na ułomności metod pomiaru produkcji potencjalnej zwracają uwagę nie tylko ekonomiści, lecz także audytorzy - Europejski Trybunał Obrachunkowy (European Court of Auditors, 2016, s. 59-60). Porównania szacunków luki produkcyjnej z kolejnych raportów Komisji Europejskiej za okres wiosna 2010 r. - wiosna 2018 r. uwidaczniają błędy o różnokierunkowym charakterze. Z raportu Komisji Europejskiej z wiosny 2018 r. wynika, że w latach 2009-2012 oszacowano ujemną lukę produkcyjną, podczas gdy analiza ex post wskazuje na lukę dodatnią w tamtym okresie (European Commission, 2018). Luka produkcyjna w latach 2013-2016 była niedoszacowana. Wyniki badań kształtowania się luki produkcyjnej w strefie euro w latach 2003-2016 również wskazują na jej niedoszacowanie średnio o 1,3 p.p. (Eyraud i in., 2018, s. 32). Błędy pomiaru produkcji potencjalnej skłaniają do ostrożności w interpretacji wyników oraz ich wykorzystywaniu w systemie nadzoru UE. Dostosowania fiskalne w krajach członkowskich, dokonywane w następstwie zaleceń Rady Unii Europejskiej wydanych w oparciu o szacunki obarczone błędem, mogą skutkować nadmiernym zacieśnieniem lub nadmiernym poluzowaniem polityki fiskalnej.

\section{Polskie doświadczenia z wdrażaniem reguły wydatkowej pod wpływem regulacji UE}

Stabilizująca reguła wydatkowa w Polsce została wprowadzona w 2013 r. i zastąpiła tymczasową regułę wydatkową, ograniczającą wzrost wydatków elastycznych i nowych prawnie zdeterminowanych wydatków budżetu państwa o 1 p.p. powyżej inflacji. Wprowadzenie nowej reguły stanowiło zarówno wdrożenie dyrektywy Rady UE z 2011 r., jak i realizację rekomendacji Rady UE z maja 2013 r. Nowa reguła swym zakresem obejmuje 98\% finansów sektora general government (GG). Spod reguły - zgodnie z prawem UE - wyłączone są wydatki budżetu ze środków europejskich oraz wydatki finansowane ze środków pochodzących z niepodlegającej zwrotowi pomocy udzielanej przez państwa członkowskie Europejskiego Porozumienia o Wolnym Handlu. Wyłączono z niej także przepływy finansowe między 
jednostkami, które nie mają zdolności do generowania wysokich deficytów z tytułu dotacji i subwencji oraz przepływy finansowe między funduszami systemu emerytalnego, zarządzane przez ZUS oraz Prezesa KRUS.

Wdrożenie reguły unijnej do prawa krajowego wymagało wypracowania metody obliczania wielkości zbliżonej do potencjalnego PKB, umożliwiającej zastosowanie metody w praktyce. Przyjęto, że odpowiednim parametrem będzie wskaźnik średniookresowej dynamiki wartości produktu krajowego brutto. Na dany rok budżetowy (rok n) jest on wyrażany w cenach stałych z dokładnością do setnych części procentu według wzoru (Ustawa z dnia 27 sierpnia 2009 r. o finansach publicznych, art. 112a pkt 1):

$$
\mathrm{WPKBn}=\sqrt[8]{\frac{P K B_{n-2}}{P K B_{n-8}}} * E_{n}\left(\frac{P K B_{n-1}}{P K B_{n-2}}\right) * E_{n}\left(\frac{P K B_{n}}{P K B_{n-1}}\right)
$$

gdzie:

WPKBn - wskaźnik średniookresowej dynamiki wartości produktu krajowego brutto w cenach stałych, określony w przedłożonym Sejmowi projekcie ustawy budżetowej na rok $n$,

$n$ - rok, na który jest obliczana kwota wydatków,

$n-1$ - rok poprzedzający rok $n$,

$n$-2 - rok poprzedzający rok $n$ o 2 lata,

$n-8$ - rok poprzedzający rok $n$ o 8 lat,

$E_{n}\left(P K B_{n-1} / P K B_{n-2}\right)-$ prognozowana w przedłożonym Sejmowi projekcie ustawy budżetowej na rok $n$ roczna dynamika wartości produktu krajowego brutto w cenach stałych w roku $n-1$,

$E_{n}\left(P K B_{n} / P K B_{n-1}\right)$ - prognozowana w przedłożonym Sejmowi projekcie ustawy budżetowej na rok $n$ roczna dynamika wartości produktu krajowego brutto w cenach stałych w roku $n$,

$P K B_{n-2} / P K B_{n-8}-$ ogłoszona przez Prezesa Głównego Urzędu Statystycznego łączna dynamika wartości produktu krajowego brutto.

W celu wyznaczenia limitu wydatków na dany rok budżetowy wskaźnik obliczony na podstawie wzoru 1 jest podstawiany do wzoru 2:

$$
W Y D n=W Y D n-1 \cdot E n-1(C C P I) \cdot[W P K B n+]+E n(\Delta D D n)
$$

gdzie:

WYDn - kwota wydatków określona w przedłożonym Sejmowi projekcie ustawy budżetowej na rok $n$,

$W Y D n-1$ - kwota wydatków określona w przedłożonym Sejmowi projekcie ustawy budżetowej na rok $n-1$,

En-1(CCPI) - poziom średniookresowego celu inflacyjnego określonego na rok n-1 przez Radę Polityki Pieniężnej w założeniach polityki pieniężnej,

$K n$ - wielkość korekty kwoty wydatków określonej w przedłożonym Sejmowi projekcie ustawy budżetowej na rok $n$, 
$E n(\Delta D D n)$ - prognozowana wartość ogółem działań dyskrecjonalnych po stronie dochodów.

Zaprezentowana powyżej formuła ustalania limitu wydatków jest aktualnie obowiązująca i różni się od koncepcji przyjętej w Polsce w 2013 r. Pierwotny kształt reguły został zmodyfikowany 10 grudnia 2015 r. przez zastąpienie wskaźnika prognozowanej inflacji wskaźnikiem średniookresowego celu inflacyjnego określonego na rok $n-1$ przez Radę Polityki Pieniężnej w Założeniach Polityki Pieniężnej. Zmiana ta może sprawiać wrażenie kosmetycznej, lecz w rzeczywistości była zasadnicza i skutkowała zmniejszeniem stopnia jej restrykcyjności oraz poluzowaniem polityki fiskalnej. Znaczenie modyfikacji reguły jest na tyle istotne, że poświęcono jej kolejny punkt niniejszej pracy. W tym miejscu skoncentrowano się natomiast na pozostałych elementach konstrukcyjnych reguły wydatkowej.

Kierując się kryterium stopnia autonomii finansowej jednostek sektora instytucji rządowych objętych zakresem reguły wydatkowej, dokonano ich podziału na dwie grupy (MF, 2014, s. 34-35). Do pierwszej zaliczono: budżet państwa, FUS, Fundusz Pracy, Fundusz Emerytalno-Rentowy, Fundusz Emerytur Pomostowych oraz fundusze utworzone, powierzone lub przekazane Bankowi Gospodarstwa Krajowego. Do drugiej grupy należą autonomiczne organy władzy państwa, np. Sejm, Senat, Prezydent, sądy i inne centralne instytucje o ustrojowym znaczeniu (Ustawa z dnia 27 sierpnia 2009 r. o finansach publicznych, art. 139 ust. 2). Podział ten ma zasadnicze znaczenie, gdyż po obliczeniu prawnie wiążącego limitu wydatków na dany rok według wzoru 2 odejmuje się od niego wielkość planowanych wydatków jednostek zaliczonych do drugiej grupy, niezależnych od władz wykonawczych przygotowujących budżet państwa. Tym samym mechanizmowi korygującemu nierównowagę $\mathrm{w}$ finansach publicznych podlegają wydatki jednostek zaliczonych do grupy pierwszej.

Regulacje unijne dopuszczają wyższe tempo wzrostu wydatków niż referencyjne tempo wzrostu potencjalnego PKB, jeżeli wzrostowi wydatków towarzyszą działania dyskrecjonalne po stronie dochodów (Regulation (EU) No. 1175/2011 of the European Parliament and of the Council of 16 November 2011, art. 5). Możliwość ta została wykorzystana przy konstrukcji polskiej reguły wydatkowej przez zapis, zgodnie z którym kwota wydatków na dany rok może być zwiększona o kwotę prognozowanych na dany rok budżetowy działań jednorazowych i tymczasowych po stronie dochodów, jeżeli wartość każdego z nich przekracza $0,3 \%$ wartości PKB prognozowanej w projekcie ustawy budżetowej. Działania te mają charakter przejściowy i nie wpływają na trwałą zmianę pozycji budżetowej (np. amnestia podatkowa, sprzedaż aktywów niefinansowych).

Przedstawiony wyżej mechanizm korygujący został wbudowany w regułę i ma charakter automatyczny. Jest on uruchamiany, gdy:

- wynik sektora instytucji rządowych i samorządowych przekroczy wartość referencyjną $3 \% \mathrm{PKB}$,

- poziom długu publicznego przekroczy wartość $43 \%$, 
- poziom długu publicznego przekroczy wartość $48 \%$,

- suma różnic odchyleń wyniku nominalnego od średniookresowego celu budżetowego (MTO) przekroczy $\pm 6 \%$ PKB.

Rodzaj podejmowanych działań i ich zakres jest uzależniony od wielu czynników, stąd dla zwiększenia przejrzystości na rysunku 1 przedstawiono go w wersji graficznej.

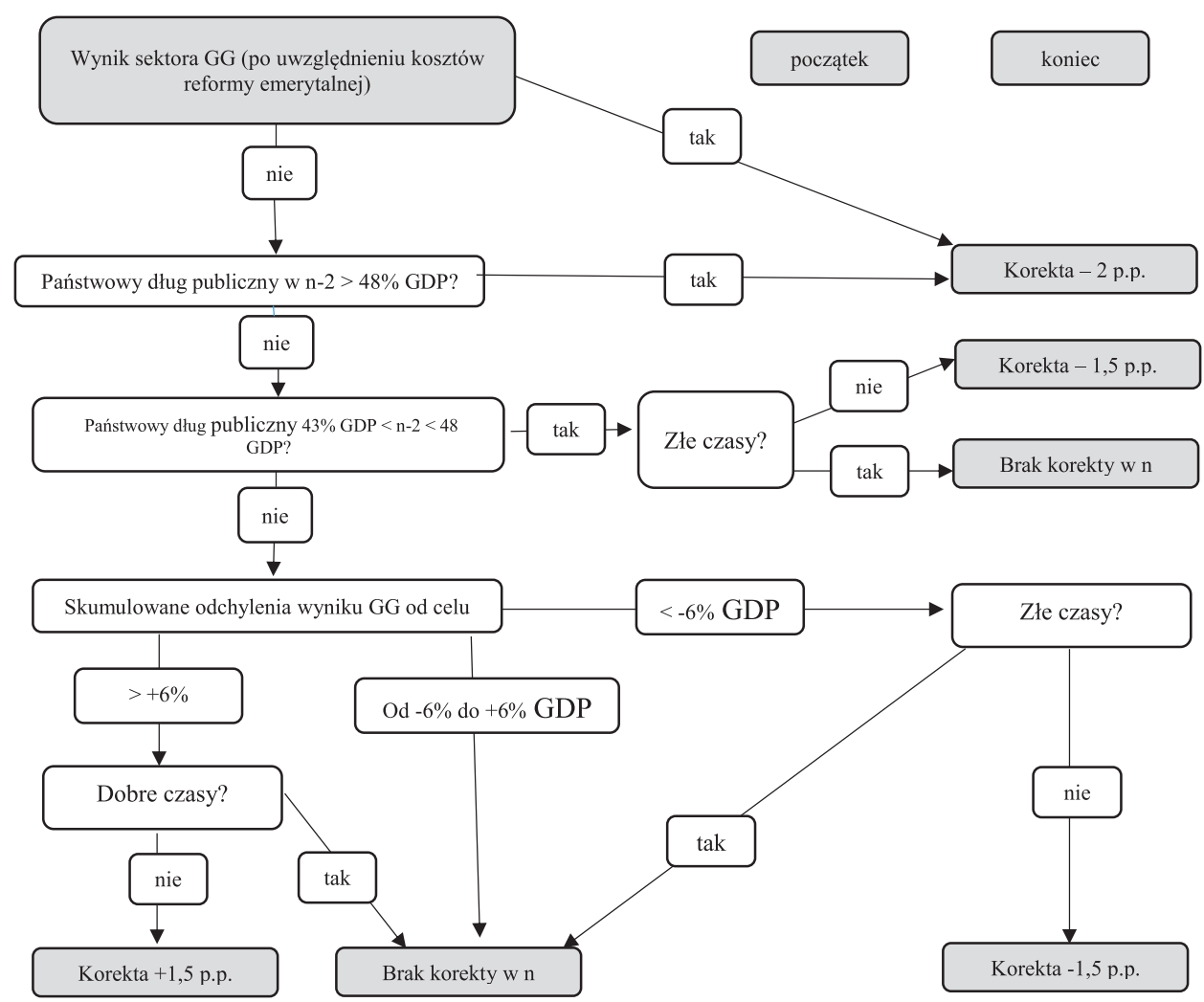

Rysunek 1. Mechanizm korygowania nierównowagi

Źródło: opracowanie własne na podstawie schematu opublikowanego przez Ministerstwo Finansów, przy uwzględnieniu wprowadzonych zmian (http://www.mf.gov.pl/documents/764034/1159274/regula_wydatkowa_informacja.pdf).

W schemacie mechanizmu korygującego uwagę zwracają określenia „dobre czasy” i ,złe czasy”, wymagające odniesienia do prognozowanej koniunktury gospodarczej. „Dobre czasy” to sytuacja, w której prognozowane przyszłoroczne realne tempo wzrostu PKB jest wyższe o ponad 2 p.p. od średniookresowego. Z kolei „złe czasy" oznaczają silne spowolnienie gospodarcze - jest ono identyfikowane, gdy prognozowane przyszłoroczne realne tempo wzrostu PKB jest niższe o ponad 2 p.p. od średniookresowego (MF, 2013). 
Punktem wyjścia dla ustalenia wielkości korekty jest kształtowanie się wyniku sektora GG i państwowego długu publicznego w roku $n-2$. Największa korekta wydatków ma zastosowanie wówczas, gdy saldo nominalne przekroczy 3\% PKB albo dług publiczny przekroczy $48 \%$ PKB. Korekta ta ma zastosowanie bez względu na prognozowaną koniunkturę gospodarczą. Koniunktura gospodarcza jest uwzględniana $\mathrm{w}$ drugim z przewidzianych przypadków, tj. gdy deficyt sektora GG przekracza 3\% PKB, a dług publiczny jest większy niż 43\%, lecz nie przekracza $48 \%$ PKB. Jeżeli powyższe warunki nie wystąpią, to korekta wydatków zależeć będzie od sumy różnic między wynikiem nominalnym sektora GG a średniookresowym celem budżetowym. W zależności od wielkości i kierunku odchylenia mechanizm przewiduje korektę zarówno w górę, jak i w dół. Wbudowanie tak skonstruowanego mechanizmu korygowania nierównowagi $\mathrm{w}$ regułę wydatkową ma jej zapewnić elastyczność.

W ustawie przewidziano trzy sytuacje, w których reguła wydatkowa nie będzie stosowana. Są to: wprowadzenie stanu wojennego, wprowadzenie stanu wyjątkowego lub wprowadzenie stanu klęski żywiołowej na całym terytorium Rzeczypospolitej Polskiej.

\section{Wpływ złagodzenia reguly wydatkowej na typ polityki fiskalnej}

Jak wspomniano, pierwotny kształt reguły został zmodyfikowany 10 grudnia 2015 r. Polegało to na zastąpieniu wskaźnika prognozowanej inflacji wskaźnikiem średniookresowego celu inflacyjnego określonego na rok $n$-1 przez Radę Polityki Pieniężnej w Założeniach Polityki Pieniężnej. Średniookresowe ujęcie celu oznacza, że ze względu na szoki makroekonomiczne i finansowe inflacja może okresowo kształtować się powyżej lub poniżej celu, w tym poza określonym przedziałem odchyleń od celu. W Polsce Rada Polityki Pieniężnej opiera politykę pieniężną na strategii bezpośredniego celu inflacyjnego. Począwszy od 2004 r., Rada wyznaczyła ciągły cel inflacyjny na poziomie $2,5 \%$ z symetrycznym przedziałem odchyleń o szerokości \pm 1 p.p.

Zmiana w regule wydatkowej wprawdzie tylko jednego, lecz istotnego parametru skutkowała poluzowaniem polityki fiskalnej. Wskaźnik CPI w ostatnich pięciu latach kształtował się poniżej celu inflacyjnego. Co więcej, w 2015 r., kiedy zdecydowano o zastąpieniu w regule wydatkowej wskaźnika prognozowanej inflacji przez stały wskaźnik celu inflacyjnego (CPI) ustalony przez bank centralny na poziomie $2,5 \%$, w polskiej gospodarce wystąpiła deflacja $(-0,9)$, utrzymująca się także w $2016 \mathrm{r}$. Obserwowana w 2017 r. inflacja $(2 \%)$ i projekcja inflacji na 2018 r. $(2,1)$ wciąż znajdują się poniżej celu inflacyjnego (rysunek 2).

Wbudowanie tak zdefiniowanego celu inflacyjnego w regułę wydatkową umożliwiło podniesienie limitu wydatków publicznych, przy czym istotne jest, że dochody budżetowe były prognozowane w oparciu o prognozowaną stopę inflacji. 


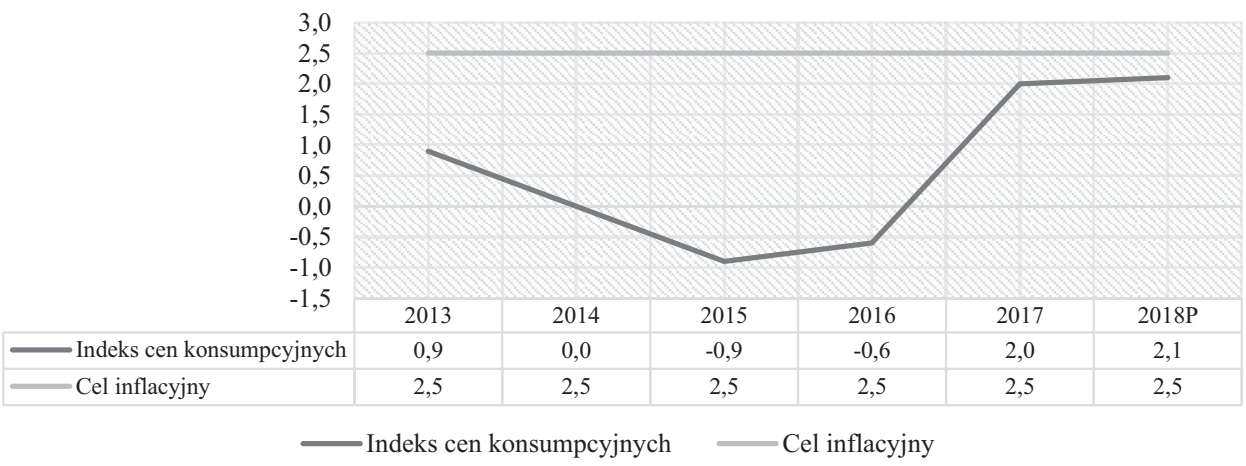

Rysunek 2. Indeks cen konsumpcyjnych i cel inflacyjny w Polsce w latach 2013-2018

$\mathrm{P}$ - projekcja Narodowego Banku Polskiego

Źródło: za lata 2013-2017 - dane Głównego Urzędu Statystycznego w Polsce (http://bdm.stat.gov.pl); projekcja na 2018 r. - Narodowy Bank Polski (http://www.nbp.pl/polityka_pieniezna/dokumenty/raport_o_inflacji/necmod_marzec_2018.pdf).

Zgodnie z założeniami przyjętymi w 2013 r. reguła wydatkowa miała mieć pozytywny wpływ na stabilizowanie cyklu koniunkturalnego. Założono ponadto, że reguła ta doprowadzi do redukcji, a następnie do stabilizacji deficytu sektora GG i w konsekwencji do zadłużenia publicznego. W celu zbadania, czy udało się zrealizować te założenia, na rysunku 3 przedstawiono zmiany nastawienia w polityce fiskalnej w latach 2013-2018. W tym celu wykorzystano metodę zastosowaną przez Alesina, Barbiero, Favero, Giavazzi i Paradisi (2015). Identyfikacji typu polityki fiskalnej dokonano na podstawie zmian w ujęciu rocznym salda pierwotnego dostosowanego cyklicznie (CABP) względem luki produkcyjnej. Wielkości te przeniesiono na układ współrzędnych, w którym każda z ćwiartek odpowiada innemu typowi polityki fiskalnej: I ćwiartka - antycykliczne zacieśnienie fiskalne, II ćwiartka procykliczne zacieśnienie fiskalne, III ćwiartka - antycykliczna ekspansja fiskalna, IV ćwiartka - procykliczna ekspansja fiskalna. Antycykliczna polityka fiskalna miała miejsce w latach, które zostały umieszczone w I i III ćwiartce. Politykę procykliczną obserwuje się natomiast w latach znajdujących się w II i IV ćwiartce.

$\mathrm{Z}$ rysunku 3 wynika, że wraz z wdrożeniem reguły wydatkowej w 2014 r. nastąpiła zmiana nastawienia w polityce fiskalnej, polegająca na odejściu od procyklicznego zacieśnienia w kierunku antycyklicznej ekspansji. W 2014 r. w okresie objętym obserwacją wystąpił jedyny epizod ekspansji fiskalnej, która łagodziła wahania koniunkturalne.

Wraz z modyfikacją reguły wydatkowej w 2015 r. można zaobserwować występujące przez dwa lata, pobudzające wahania koniunkturalne, zacieśnienie fiskalne (2015-2016). W kolejnym roku polityka fiskalna też była procykliczna, cechowała ją jednak ekspansja, która utrzyma się w latach następnych, co można wnioskować na podstawie prognoz i planów zwiększenia wydatków socjalnych. Analizy 


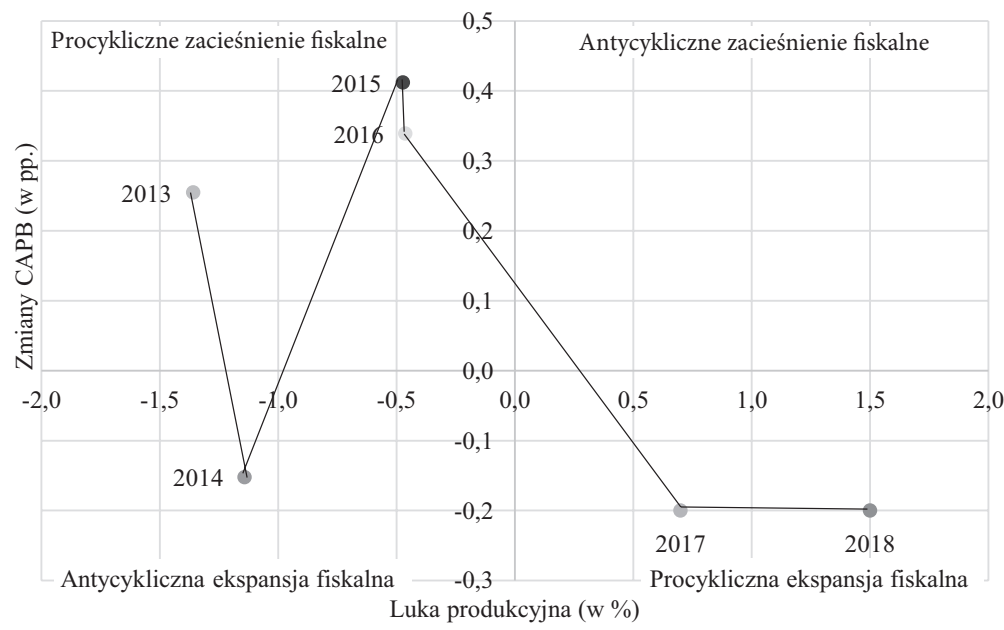

Rysunek 3. Nastawienie w polityce fiskalnej w Polsce w latach 2013-2018

Uwaga: na 2018 r. - prognoza

Źródło: opracowanie własne na podstawie bazy danych AMECO (http://ec.europa.eu/economy_finance/ameco).

te pozwalają na wyciągnięcie wniosku, iż wprowadzenie w 2014 r. w życie reguły wydatkowej w oparciu o wskaźnik prognozowanej inflacji sprzyjało prowadzeniu stabilizacyjnej polityki fiskalnej. Zmiany w nastawieniu w polityce fiskalnej od czasu modyfikacji reguły wydatkowej sugerują, że straciła ona właściwości łagodzenia wahań koniunkturalnych.

Złagodzenie reguły wydatkowej było wynikiem realizowanej doktryny gospodarczej, która uległa zmianie po wyborach parlamentarnych w 2015 r. Realizacja programów wyborczych wymagała zaangażowania większych środków publicznych na programy socjalne, tj. Program ,Rodzina 500 plus”. Program ten zapewnia finansowe wsparcie w wysokości 500 zł miesięcznie na każde drugie i kolejne dziecko. Rodziny o niskich dochodach otrzymują świadczenie także na pierwsze lub jedyne dziecko. Program wymaga zaangażowania dużych środków finansowych. W 2017 r. wydatki na ten cel wyniosły 23,2 mld PLN, co stanowiło 6,2\% wydatków oraz 95,5\% deficytu budżetu państwa. Finansowanie nowych wydatków bieżących wymagało działań dyskrecjonalnych po stronie dochodowej i wydatkowej. Jednoczesna poprawa salda nominalnego w 2017 r. była wynikiem lepszej koniunktury gospodarczej (stopa wzrostu PKB wyniosła 4,6\%), pozyskania środków dyskrecjonalnych po stronie dochodowej na finansowanie wydatków bieżących oraz spadku wydatków kapitałowych. Dane zamieszczone na rysunku 4 sugerują, że rozluźnienie reguły wydatkowej skutkowało ekspansją fiskalną pobudzającą wahania koniunkturalne.

Warto dodać, że w 2014 r., gdy funkcjonowała reguła wydatkowa w pierwotnym, bardziej rygorystycznym kształcie, a polityka fiskalna miała charakter hamujący 


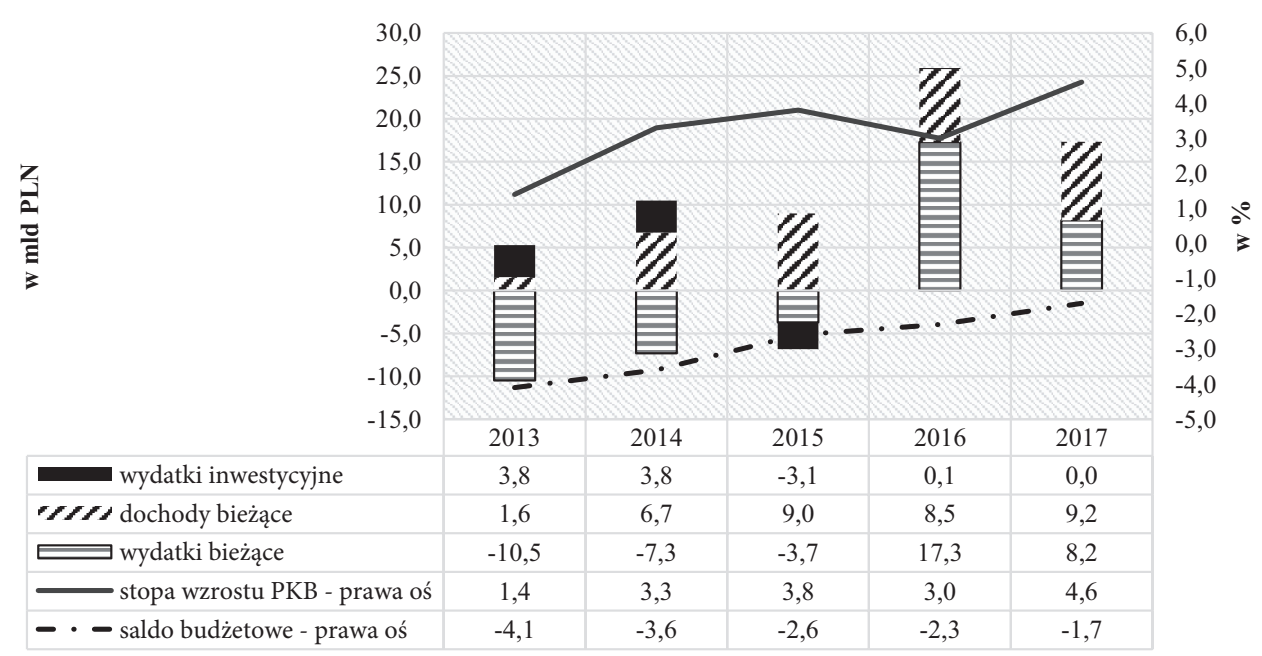

Rysunek 4. Środki dyskrecjonalne (w mld PLN) na tle stopy wzrostu PKB w ujęciu realnym (w \%) i salda budżetowego (\% PKB)

Źródło: baza danych AMECO (http://ec.europa.eu/economy_finance/ameco) i baza danych Eurostat (http://ec.europa. eu/eurostat).

wahania cykliczne, dokonano cięć w wydatkach bieżących przy wzroście wydatków inwestycyjnych (kapitałowych). Działanie to było zgodne z rekomendacjami Rady Ecofin, według których konsolidacja fiskalna nie może dokonywać się przez cięcia wydatków inwestycyjnych (MF, 2015, s. 307).

\section{Zakończenie}

Zgodnie z zaleceniami teorii reguła fiskalna powinna być prosta. Tymczasem stabilizująca reguła wydatkowa w Polsce nie ma prostej konstrukcji, lecz jest rozbudowanym, zależnym od wielu zmiennych modelem, z wkomponowanym (równie złożonym) automatycznym mechanizmem korygującym nierównowagę w finansach publicznych. Konstrukcja krajowej reguły wydatkowej jest na tyle skomplikowana, że zyskała miano „matematyki dla zaawansowanych” (Gadomski, 2013). Realizacja celów politycznych i gospodarczych w warunkach funkcjonowania tej reguły prowadzi do niekorzystnej zmiany struktury wydatków publicznych, tj. zwiększania wydatków bieżących (socjalnych) kosztem wydatków kapitałowych. O ile wydatki na cele socjalne skutkują wzrostem konsumpcji wpływającej na wzrost gospodarczy w krótkim okresie, o tyle ograniczanie wydatków kapitałowych oddziałuje negatywnie na potencjał wzrostu gospodarki w długim okresie. Wbrew założeniom reguła nie hamuje, lecz pobudza wahania koniunkturalne. Polityka fiskalna po zastąpieniu w regule wskaźnika prognozowanej inflacji wskaźnikiem CPI, pozwalającym na 
zwiększenie limitu wydatków na realizację m.in. programów społecznych, ma charakter pobudzającej cykl ekspansji wydatkowej.

Wskaźnik siły reguły wydatkowej (Fiscal Rule Strength Index) dla Polski wynosi tylko 5,27. Do słabej oceny reguły wydatkowej przyczynił się w dużym stopniu brak niezależnego organu odpowiedzialnego za ustalanie odstępstwa od celu oraz dostarczającego (zatwierdzającego) prognozy makroekonomiczne i/lub budżetowe. Polska nie zdecydowała się dotychczas na powołanie agencji fiskalnej (rady fiskalnej), do ustanowienia której zobowiązuje dyrektywa Rady UE (Council Directive 2011/85/ EU of 8 November 2011). Konkludując, dobrze skonstruowane numeryczne reguły fiskalne mogą być ważnym instrumentem dyscyplinowania finansów publicznych, lecz doświadczenia z regułą wydatkową w Polsce dostarczają wielu argumentów przeciwnikom stosowania reguł numerycznych w polityce fiskalnej.

\section{Bibliografia}

Alesina, A., Barbiero, O., Favero, C., Giavazzi, F., Paradisi, M. (2015, July). Austerity in $2009-2013$. (Economic Policy).

Beetsma, R.M.W.J., Bovenberg, A.L. (2001). The Optimality of a Monetary Union without a Fiscal Union. Journal of Money, Credit and Banking, Blackwell Publishing, 33(2).

Berger, H., Dell'Ariccia, G., Obstfeld, M. (2018). Revisiting the Economic Case for Fiscal Union in the Euro Area. Washington: International Monetary Fund Research Department.

Buchanan, J.M. (1997). Finanse publiczne w warunkach demokracji. Warszawa: PWN.

Buiter, W.H. (2003). Ten commandments for a fiscal rule in the E(M)U. Oxford Review of Economic Policy, 19(1). doi:10.1093/oxrep/19.1.84

Council Directive 2011/85/EU of 8 November 2011 on requirements for budgetary frameworks of the Member States (OJ EU L 306/41, 23.11.2011).

European Commission (2010). Public finances in EMU - 2010. European Economy, (4).

European Commission (2018, 22 October). Adjustment of Budget Balances.

European Court of Auditors (2016). Further improvements needed to ensure effective implementation of the excessive deficit procedure. Special Report. Luxembourg.

Eyraud, L., Debrun, X., Hodge, A., Lledó, V., Pattillo, C. (2018, April). Second-Generation Fiscal Rules: Balancing Simplicity, Flexibility, and Enforceability. (IMF Staff Discussion Note, SDN/18/04).

Gadomski, W. (2013). Nowa reguła wydatkowa to matematyka dla zaawansowanych. Pobrane z: https:// www.obserwatorfinansowy.pl/almanach/nowa-regula-wydatkowa-czyli-matematyka-dla-zaawansowanych

IMF (2009, 16 December). Fiscal Rules - Anchoring Expectations for Sustainable Public Finances. Report prepared by the Fiscal Affairs Department.

MF (2013). Stabilizujaca reguła wydatkowa. Pobrane z: https://www.mf.gov.pl/documents/764034/1159274/ regula_wydatkowa_informacja.pdf

MF (2014). Strategia zarządzania dtugiem sektora finansów publicznych w latach 2015-2018. Warszawa (wrzesień).

MF (2015). Sprawozdanie z wykonania budżetu państwa z okres od 1 stycznia do 31 grudnia 2014 r. Omówienie. Warszawa.

Moździerz, A. (2015). Strengthening the Post-crisis Fiscal Rules - the Case of Spain, Slovakia and Sweden. Equilibrium. Quartely Journal of Economics and Economic Policy, 10(2).

doi:10.12775/EQUIL.2015.012 
Moździerz, A. (2017). Fiscal supervision as an element of new economic governance in the European Union. W: S. Owsiak (ed.), Public Finances and the New Economic Governance in the European Union. Warszawa: PWN.

Moździerz, A. (2018). The impact of EU regulations on the construction of national fiscal rules - case of Poland. W: J. Mészaros (ed.), Fiscal Rules in the EU after the Crisis. A Selection of Papers Presented During the Budapest Public Finance Seminar 2018. Budapest: Hungarian State Treasury.

Postuła, M., Klepacki, J. (2018). Reguły długu publicznego stabilizatorem finansów publicznych Grupy Wyszehradzkiej. Prace Naukowe Uniwersytetu Ekonomicznego we Wroctawiu, (532).

Próchnicki, L. (2013). Reguły fiskalne a stabilność fiskalna krajów Unii Europejskiej. Zeszyty Naukowe Uniwersytetu Szczecińskiego. Studia i Prace Wydziału Nauk Ekonomicznych i Zarzadzania, (32).

Przybylska-Mazur, A. (2017). Podejmowanie optymalnych decyzji fiskalnych w aspekcie wzrostu gospodarczego. Studia Ekonomiczne. Zeszyty Naukowe Uniwersytetu Ekonomicznego w Katowicach, (331).

Regulation (EU) No. 1175/2011 of the European Parliament and of the Council of 16 November 2011 amending Council Regulation (EC) No. 1466/97 on the strengthening of the surveillance of budgetary positions and the surveillance and coordination of economic policies (OJ EU L 306/12, 23.11.2011).

Ustawa z dnia 27 sierpnia 2009 r. o finansach publicznych (t.j. Dz.U. 2017, poz. 2077; Dz.U. 2018, poz. 62). 